\title{
Effect of Deha Prakruti on Intelligence - An Appraisal
}

\author{
Review Article
}

\section{Navoday Raju N R', Raole Vaidehi²*}

1. Ph.D Scholar and Assistant Professor, 2. Professor and Academic Coordinator, Department of Kriya Sharir, Parul Institute of Ayurved and Research, Parul University, Vadodara, Gujarat.

\begin{abstract}
Ayurveda lays great emphasis on the concept of Prakruti (body constitution) in the diagnosis, prognosis and treatment. Panchamahabhoota (five basic elements of the universe) in different permutation and combination form Tridosha (three humors of the body). Prakruti is formed depending on the predominance of any one or two or three Dosha at the time of conception. Prakruti is of two types: Dosha Prakruti or Deha Prakruti and Gunamayi Prakruti or Manasa Prakruti. Deha Prakruti is of 7 types. Vataja, Pittaja, Sleshmaja, Samsargaja [combination of two Dosha] i.e., Vata-Pitta, Pitta-Sleshma, Sleshma-Vata and Sannipataja [combination of three Dosha] i.e., Vata-Pitta-Sleshma. The person of each Prakruti is mentioned to be endowed with different characteristic features which includes physical and psychological features, abilities etc. Medha (intelligence), Smruti (memory) are psychological factors differentiating one person from other with respect to ability to perform any task. Prakruti is the deciding factor of various psychological characters including Medha. This article aims at studying the effect of Deha Prakruti on intelligence.
\end{abstract}

Key Words: Ayurveda, Prakruti, Medha, Intelligence quotient, Smruti, Memory.

\section{Introduction}

The concept of Prakruti is a unique contribution of Ayurveda. Great emphasis has been laid on the examination of Prakruti which is the natural state of an individual. This is very important because only by understanding the original state of the body function one can understand the possible derangement in the functioning. The primary aim of Ayurveda is also to maintain health in healthy person (1) and hence knowledge of Prakruti is imperative. Prakruti is further categorized into two i.e. Deha Prakruti and Manasa Prakruti. Deha Prakruti is categorized into 7 types i.e. 3 Ekadoshaja, 3 Dwidoshajal Samsargaja and 1 Tridoshajal Sannipataja. Different Deha Prakruti individuals are endowed with variations in their psychological as well as physical features. (2)

Intelligence is the aggregate or global capacity of the individual to act purposefully, to think rationally and to deal effectively with his environment (Wechsler, 1944, p.3). (3) A universally accepted uniform definition of intelligence has yet not evolved by the psychologists.

Intelligence quotient (IQ) is the measure of intelligence. It is the ratio of individual's mental age to his or her chronological age. An individual's I.Q.

\section{* Corresponding Author:}

\section{Raole Vaidehi}

Professor, Department of Kriya Sharir,

Academic Coordinator, Parul Institute of Ayurved,

Parul University, Vadodara,

Gujarat. India

Email Id: pandeakshara@gmail.com indicates the rate of mental development or the degree of brightness. If the mental development keeps pace with one's life age, the quotient is 100 . (4)

\section{Aim and Objective}

This article aims at studying the effect of Deha Prakruti on intelligence.

\section{Materials and Methods}

Ayurvedic classical texts and online sources are referred for the better understanding of the concept of Deha Prakruti and its effect on intelligence.

\section{Literary Review \\ Dosha}

Vata Pitta and Kapha are Tridosha. Dosha are in a state of dominance in their physiological limits to form Prakruti. (5) Persons of different Prakruti get influenced by Dosha and Dosha Guna.

\begin{tabular}{|l|l|l|l|}
\hline \multicolumn{4}{|c|}{ Table 1: Dosha Guna (6) } \\
\hline Vagbhata & \multicolumn{1}{|c|}{ Pitta } & \multicolumn{1}{c|}{ Kapha } \\
Ruksha (dry) & Snigdha & Snigdha \\
& Laghu (light) & (unctuous) & (unctuous) \\
& Sheeta (cool) & Teekshna & Sheeta (cool) \\
& Khara (rough) & (penetrating) & Guru (heavy) \\
& Sukshma (subtle) & Ushna (hot) & Manda (slow) \\
& Chala (mobile) & Laghu (light) & Slakshna \\
& & Visra (foetid) & (fine) \\
& & Sara (flowing) & Mritsna \\
& & Drava (liquid) & (sticky) \\
& & & Sthira (stable) \\
& & & \\
& & &
\end{tabular}




\begin{tabular}{|c|c|c|c|}
\hline Sushruta & $\begin{array}{l}\text { Ruksha, Laghu, } \\
\text { Sheeta, Khara }\end{array}$ & $\begin{array}{l}\text { Teekshna, } \\
\text { Drava, } \\
\text { Pooteegandha, } \\
\text { Neela, Peeta, } \\
\text { Ushna, } \\
\text { Katurasa, } \\
\text { Amlarasa in } \\
\text { Vidagdha state }\end{array}$ & $\begin{array}{l}\text { Shweta, Guru, } \\
\text { Snigdha, } \\
\text { Picchila, } \\
\text { Sheeta, } \\
\text { Madhura, } \\
\text { Lavana in } \\
\text { Vidagdha state }\end{array}$ \\
\hline Charaka & $\begin{array}{l}\text { Ruksha, Laghu, } \\
\text { Sheeta, Daruna, } \\
\text { Chala, Vishada, } \\
\text { Khara, Sukshma }\end{array}$ & $\begin{array}{l}\text { Slightly } \\
\text { Snigdha, } \\
\text { Ushna, } \\
\text { Teekshna, } \\
\text { Drava, Aamla, } \\
\text { Sara, Katu }\end{array}$ & $\begin{array}{l}\text { Guru, Sheeta, } \\
\text { Mridu, } \\
\text { Snigdha, } \\
\text { Madhura, } \\
\text { Sthira, } \\
\text { Picchila }\end{array}$ \\
\hline
\end{tabular}

\section{Prakruti}

Physique, personality, Agni, Bala, mental faculties, Koshta, progeny, Swapna etc., differs from one person to another. Structure/ Shape of the body, attitude of the person not only depend on Aahaara Prakara (type) or Vihaara (lifestyle) etc., but also depend on Prakruti of the person. (7)(8)

Prakruti is decided at the time fertilization. Dosha dominant at the time of fertilization decides the Prakruti of a person. It remains constant for lifetime. The Dosha which are present in the Shukra and Aartava at the time of commencement of life decides the Prakruti. (9)

\section{Classification of Prakruti}

Prakruti is classified into two types: Deha Prakruti and Manasa Prakruti. Deha Prakruti is of 7 types with involvement of one or two or three Dosha. (10)

- Vatala (Vata Pradhana Prakruti): Individuals possess strength, span of life, procreation, accessories of life and wealth in lesser quantity. (11)

- Pittala (Pitta Pradhana Prakruti): Endowed with moderate strength, span of life, spiritual and materialistic knowledge, wealth and accessories of life. (12)

- Sleshmala (Sleshma Pradhana Prakruti): Gifted with excellence of strength, wealth, knowledge, energy, peace and longevity. (13)

Dwidoshaja/ Samsargaja Prakruti persons are endowed with characteristic features of both the Prakruti and Tridoshaja/ Sannipataja Prakruti persons are endowed with characters of all three Prakruti.

\section{Factors influencing Prakruti}

Dosha that is predominant in the Shukra and Shonita at the time of union, food and activities of the pregnant women, uterus and season influences the Prakruti. (14) (15) Other factors influencing Prakruti includes inherited characters from father (Pitruja), mother (Maatruja), Soul (Aatmaja), mind (Sattvaja), diet (Rasaja) and homologation (Satmyaja). (16) (17)

\section{Medha}

It is specific part of Buddhi (intellect/ discriminative power) which has the power of retaining the knowledge for a long period. Due to Medha a person will be able to obtain the knowledge of existing objects and hence person becomes learned. (18)

Practically the word 'Medha' is used to denote higher intellect. The word 'Medhavi' is used for the person who is the knower of various Shastra (literature) and having Pratyutpanna Mati. Sometimes 'Medha' is also used for extraordinary recollection power. Acharya Dalhana defines 'Medha' very clearly as the capacity to retain knowledge of various texts. (19)

In nutshell it can be concluded that Medha is the faculty of Buddhi which has the power to grasp (20) the experiences or knowledge and when needed it recalls that retained knowledge as it is. (21). Smruti means remembrance of things directly perceived, heard or experienced (22), Dhruti means patience which can retrain the mind from its harmful object (23), Medha is assessed by Dharana Shakti (grasping power). (24)

\section{Intelligence}

The capacity for logic, understanding, self awareness, learning, emotional knowledge, reasoning, planning, creativity, critical thinking and problem solving is called as intelligence. Generally, it is considered as the ability to perceive or infer information, and to retain it as knowledge. Intelligence Quotient (IQ) is the measure of intelligence. (25)

\section{Intelligence Quotient (IQ)}

It is the measure of intelligence derived as a total score from a set of standardized tests or subtests designed to assess human intelligence. There are various tests available for the assessment of IQ, common tests being Wechsler Adult Intelligence Scale (WAIS), Wechsler Intelligence Scale for Children (WISC) and Stanford-Binet Intelligence Scale etc. (26)

\section{Measurement of IQ}

Indian adaptation of Wechsler's Adult Intelligence Scale, Version-IV (WAIS-IV) composed of 10 core subtests and five supplemental subtests can be utilized for yielding scaled scores that sum to derive the Full-Scale IQ. Scores of Verbal Comprehension Index (VCI), Perceptual Reasoning Index (PRI), Working Memory Index (WMI) and Processing Speed Index (PSI) gives rise to Full Scale Intelligence Quotient (FSIQ). 
Table 2: Information of Indices, Subtests of WAIS-IV (27)

\begin{tabular}{|c|c|c|c|}
\hline Index & Subtest & Description & Proposed abilities measured \\
\hline \multirow{3}{*}{$\begin{array}{l}\text { Verbal Comprehension } \\
\text { (ability to understand spoken } \\
\text { language) }\end{array}$} & Similarities & $\begin{array}{l}\text { Describe how two or concepts are } \\
\text { similar }\end{array}$ & $\begin{array}{l}\text { Abstract verbal reasoning; } \\
\text { semantic knowledge }\end{array}$ \\
\hline & Vocabulary & $\begin{array}{l}\text { Name objects in pictures or define } \\
\text { words presented to them }\end{array}$ & $\begin{array}{l}\text { Semantic knowledge; verbal } \\
\text { comprehension and expression }\end{array}$ \\
\hline & Information & General knowledge questions & $\begin{array}{l}\text { Degree of general information } \\
\text { acquired from culture }\end{array}$ \\
\hline \multirow[t]{3}{*}{$\begin{array}{l}\text { Perceptual Reasoning } \\
\text { (ability to think } \\
\text { and reason using pictures/ } \\
\text { visual information) }\end{array}$} & Block Design & $\begin{array}{l}\text { Put together red and white blocks in a } \\
\text { pattern according to a displayed model. } \\
\text { This is timed, and some of the more } \\
\text { difficult puzzles award bonuses for } \\
\text { speed }\end{array}$ & $\begin{array}{l}\text { Visual spatial processing and } \\
\text { problem solving; visual motor } \\
\text { construction }\end{array}$ \\
\hline & Matrix Reasoning & $\begin{array}{l}\text { View an array of pictures with one } \\
\text { missing square, and select the picture } \\
\text { that fits the array from five options }\end{array}$ & $\begin{array}{l}\text { Nonverbal abstract problem } \\
\text { solving, inductive reasoning }\end{array}$ \\
\hline & Visual Puzzles & $\begin{array}{l}\text { View a puzzle in a stimulus book and } \\
\text { choose from among pieces of which } \\
\text { three could construct the puzzle }\end{array}$ & Visual spatial reasoning \\
\hline \multirow{2}{*}{$\begin{array}{l}\text { Working Memory } \\
\text { (a limited capacity store for } \\
\text { retaining information for a } \\
\text { brief period while performing } \\
\text { mental operations on that } \\
\text { information) }\end{array}$} & Digit Span & $\begin{array}{l}\text { Listen to sequences of numbers orally } \\
\text { and to repeat them as heard, in reverse } \\
\text { order, and in ascending order }\end{array}$ & $\begin{array}{l}\text { Working memory, attention, } \\
\text { encoding, auditory processing }\end{array}$ \\
\hline & Arithmetic & $\begin{array}{l}\text { Orally administered timed, arithmetic } \\
\text { word problems }\end{array}$ & $\begin{array}{l}\text { Quantitative reasoning, } \\
\text { concentration, mental } \\
\text { manipulation }\end{array}$ \\
\hline \multirow[t]{2}{*}{$\begin{array}{l}\text { Processing Speed } \\
\text { (pace at which you take in } \\
\text { information, make sense of it, } \\
\text { and begin to respond) }\end{array}$} & Symbol Search & $\begin{array}{l}\text { View rows of symbols and target } \\
\text { symbols, and mark whether or not the } \\
\text { target symbols appear in each row }\end{array}$ & Processing speed \\
\hline & Coding & $\begin{array}{l}\text { Transcribe a digit-symbol code using a } \\
\text { key. The task is time-limited }\end{array}$ & $\begin{array}{l}\text { Processing speed, associative } \\
\text { memory, graphomotor speed }\end{array}$ \\
\hline
\end{tabular}

\section{Medha vis-à-vis Intelligence and IQ}

Medha is the ability to grasp the information and retain it as the knowledge which can be correlated with intelligence i.e. the capacity to perceive the information and retain it as knowledge. Intelligence quotient being the measure of intelligence can be utilized for measuring Medha too.

\section{Relation between Deha Prakruti and Intelligence}

- Vatala and Intelligence: In the characteristics of Vata Prakruti individuals because of predominance of Vata Dosha,Vata Guna Amshaamsha influence is seen in them. According to Acharya Charaka, due to the Sheeghra Guna they seems quick in understanding (grasping) but weak in recalling things means they have good short term memory but poor long term memory. (28) While Acharya Sushruta has said that they have lack of patience and less discriminative power. (29) According to Acharya Vagbhata, they are unsteady in respect of Dhruti, Smruti, Buddhi and Cheshta (activities). (30)

- Pittala and Intelligence: According to Acharya Charaka, Pitta Prakruti persons are endowed with moderate spiritual and materialistic knowledge. (31) As per Acharya Sushruta and Acharya Vagbhata,
Pitta Prakruti person is highly intelligent, clever and loves to monopolise the conversation. (32) (33) (34)

- Sleshmala and Intelligence: According to Acharya Charaka, Kapha Prakruti persons are endowed with excellent knowledge. (35) Kapha Prakruti person is endowed with self control and having strong faith in Shastra. (36) He is intelligent, takes more time to grasp any subject but possessed with long term memory. (37)

\section{Discussion Prakruti and IQ}

Pragnyaparadha (intellectual blasphemy) is responsible for aggravation all the Dosha. (38) The indulgence in Pragnyaparadha is due to impairment of intellect, patience and memory which are different in different Prakruti individuals. Health and mortality depend on IQ. Higher IQs in early life are associated with lower mortality and morbidity rates in later life. (39)

VCI (assessing the ability to understand spoken language) and PRI (assessing the ability to think and reason) must be more in Pittala persons because of Teekshna Guna and Laghu Guna of Pitta Dosha. VCI 
must be least in case of Sleshmala persons because of Manda Guna and Guru Guna of Kapha Dosha.

WMI (assessing the capacity for retaining information for a brief period while performing mental operations on that information) must be more in Sleshmala persons because of Sthira Guna and Snigdha Guna of Kapha Dosha and must be least in case of Vatala persons because of Chala Guna and Ruksha Guna of Vata Dosha.

PSI (assessing the pace at which one take in information, make sense of it, and begin to respond) must be more in Pittala persons because of Teekshna Guna, Utsaaha Karma Laghu Guna of Pitta Dosha and least in Sleshmala persons because of Manda Guna and Guru Guna of Kapha Dosha.

Pittala persons are said to have more Medha so, FSIQ must be more in them because of Teekshna Guna and Laghu Guna of Pitta Dosha. Vatala persons are said to have least Medha so also FSIQ due to Chala Guna, Ruksha Guna of Vata Dosha.

\section{Genetics, Environment and IQ}

Environmental and genetic factors play a role in determining IQ. Their relative importance has been the subject of much research and debate. (40) Applied Ayurveda concept i.e. "Ayurgenomics" can contribute vastly in this avenue. Utilization of Prakruti concept can guide the researches in the right direction.

\section{Physiology of Intelligence and Prakruti}

High IQ is associated with combinations of neurological parameters which determine an intermediate degree of "arousability" in the cerebral cortex and related structures. This relationship is accounted for in terms of the generally optimal effect that an intermediate degree of arousability would have on different neuro-physiological processes mediating the acquisition, retention and utilization of information. (41) Prakruti wise differences in abilities such as discriminative, grasping, retaining, recollection of things etc. can be inferentially correlated with these neuro-physiological processes responsible for variations in intelligence.

\section{Applicability of the Concept}

Prakruti based intelligence can be utilized in Cognitive Epidemiology. It is field of research that examines the associations between intelligence test scores and health. Intelligence assessment through Prakruti can be an important predictor of later health and mortality differences at early age. It can even help in testing school performance of a student, predicting job performance of an employee, personalized medicine, determining suitability of profession according to Prakruti and expecting earning abilities etc. (42)

\section{Conclusion}

By knowing Prakruti one can understand different physical and psychological attributes and behavioral changes. Intelligence can be inferentially assessed based upon the Prakruti of an individual. Pitta
Prakruti persons are endowed with more intelligence, Kapha Prakruti persons with moderate and Vata Prakruti persons with least intelligence. Knowledge of Intelligence in accordance with Prakruti can contribute a lot in research thrust areas like Personalized Medicine and Ayurgenomics etc.

\section{References}

1. Sharma R K, Dash B. English translation on Charaka Samhita of Agnivesha, Volume 1, Sutra Sthana; Dashamahamooleeyam: Chapter 30, Verse 26: Reprint edition. Varanasi; Chowkhambha Sanskrit Series; 2014, 600-01p.

2. Paradakara HSS. Ashtanga Hrudaya with Sarvangasundara commentary of Arunadutta and Ayurveda Rasayana commentary of Hemadri. 9 ${ }^{\text {th }}$ edition. Varanasi; Chaukhambha Orientalia; 2005, $8 \mathrm{p}$.

3. http://www.intelltheory.com/wechsler.shtml dated 02-05-2021 time 14.04 IST

4. https://en.wikipedia.org/wiki/Mental_age dated 02-05-2021 time 14.15 IST

5. Sharma PV. Sushruta Samhita. Volume 2, Shareera Sthana; Garbhavyakarana Shareeram: Chapter 4, Verse 63: Reprint edition. Varanasi; Chaukhambha Bharati Academy; 2010. 162p.

6. Sreekumar T. Astangahrdaya. 2ed. Thrissur (India); Harisree Hospital; 2008. 37p.

7. Sharma RK, Dash B. English translation on Charaka Samhita of Agnivesha, Volume 1, Vimana Sthana; Rogabhishagjiteeyam Vimanam: Chapter 8, Verse 95: Reprint edition. Varanasi; Chowkhambha Sanskrit Series; Varanasi, 2014. 262p.

8. Sreekumar T. Astangahrdaya. 2ed. Thrissur (India); Harisree Hospital; 2008. 34p.

9. Sharma PV. Sushruta Samhita. Volume 2, Shareera Sthana; Garbhavyakarana Shareeram: Chapter 4, Verse 63: Reprint edition. Varanasi; Chaukhambha Bharati Academy; 2010. 162p.

10. Sharma PV. Sushruta Samhita. Volume 2, Shareera Sthana; Garbhavyakarana Shareeram: Chapter 4, Verse 62: Reprint edition. Varanasi; Chaukhambha Bharati Academy; 2010. 162p.

11. Sharma RK, Dash B. English translation on Charaka Samhita of Agnivesha, Volume 2, Vimana Sthana; RogabhishagjiteeyamVimanam: Chapter 8, Verse 96-99: Reprint edition.Varanasi; Chowkhambha Sanskrit Series; 2014, 265-66p.

12. Sharma RK, Dash B. English translation on Charaka Samhita of Agnivesha, Volume 2, Vimana Sthana; RogabhishagiiteeyamVimanam: Chapter 8, Verse 96-99: Reprint edition.Varanasi; Chowkhambha Sanskrit Series; 2014, 264-65p.

13. Sharma RK, Dash B. English translation on Charaka Samhita of Agnivesha, Volume 2, Vimana Sthana; RogabhishagjiteeyamVimanam: Chapter 8, Verse 96-99: Reprint edition.Varanasi; Chowkhambha Sanskrit Series; 2014, 263-64p.

14. Paradakara HSS. Ashtanga Hrudaya with Sarvangasundara commentary of Arunadutta and Ayurveda Rasayana commentary of Hemadri. 9 ${ }^{\text {th }}$ 
edition. Varanasi; Chaukhambha Orientalia; 2005, 9-10p.

15. Sharma RK, Dash B. English translation on Charaka Samhita of Agnivesha, Volume 2, Vimana Sthana; RogabhishagjiteeyamVimanam: Chapter 8, Verse 95: Reprint edition.Varanasi; Chowkhambha Sanskrit Series; 2014, 262p.

16. Sharma RK, Dash B. English translation on Charaka Samhita of Agnivesha, Volume 2, Vimana Sthana; RogabhishagjiteeyamVimanam: Chapter 8, Verse 95: Reprint edition.Varanasi; Chowkhambha Sanskrit Series; 2014, 262p.

17. Acharya YT. Sushruta Samhita with Nibandhasangraha commentary of Sri Dalhanacharya. Reprint edition. Varanasi; Chaukambha Sanskrit Samsthan; 2010, 354p.

18. Bahadur RKD. Shabdakalpadruma, Volume 3, 3rd edition. Varanasi; Chaukhambha Sanskrit Series; 2002, 780p.

19. Acharya YT. Susurta Samhita with Nibandhasangraha Commentary by Dalhana, Reprint edition, Varanasi; Choukhambha Sanskrit Samsthan; 2010. 10p.

20. Sharma RK, Dash B. English translation on Charaka Samhita of Agnivesha, Volume 2, Vimana Sthana; Trividha Roga Vishesha Vijnaneeyam: Chapter 4, Verse 8: Reprint edition.Varanasi; Chowkhambha Sanskrit Series; 2014, 167p.

21. Paradara HSS. Ashtanga Hrudaya with Sarvangasundara Commentary of Arunadutta and Ayurveda Rasayana Commentary of Hemadri. 9th edition. Varanasi; Chaukambha Orientalia; 2005,182p.

22. Sharma RK, Dash B. English translation on Charaka Samhita of Agnivesha, Volume 2, Shareera Sthana; Katidhapurusheeyam: Chapter 1, Verse 149: Reprint edition.Varanasi; Chowkhambha Sanskrit Series; 2014, 348p.

23. Sharma RK, Dash B. English translation on Charaka Samhita of Agnivesha, Volume 2, Shareera Sthana; Katidhapurusheeyam: Chapter 1, Verse 100: Reprint edition.Varanasi; Chowkhambha Sanskrit Series; 2014, 337p.

24. Sharma RK, Dash B. English translation on Charaka Samhita of Agnivesha, Volume 2, Vimana Sthana; Trividha Roga Vishesha Vijnaneeyam: Chapter 4, Verse 8: Reprint edition.Varanasi; Chowkhambha Sanskrit Series; 2014, 167p.

25. ht tp s:// e n.wikipedia.org/wiki/ Intelligence_quotient\#Current_tests dated 19-05-2021 time 21.05 IST

26. ht t p s : / / e n.wikipedia.org/w i ki/ IQ_classification\#IQ_classification_tables_for_curr ent_tests dated 19-05-2021

27. David Wechsler. Technical and Interpretive Manual. Bengaluru; PsychCorp; 2008. 8-16p.

28. Acharya YT. Agnivesha Charaka Samhita with Ayurveda Dipika commentary of Cakrapanidutta. Reprint edition. Varanasi; Chaukambha Sanskrit Samsthan; 2011, 277p.
29. Acharya YT. Sushruta Samhita with Nibandhasangraha commentary of Sri Dalhanacharya. Reprint edition. Varanasi; Chaukambha Sanskrit Samsthan; 2010, 361p.

30. Paradakara HSS. Ashtanga Hrudaya with Sarvangasundara commentary of Arunadutta and Ayurveda Rasayana commentary of Hemadri. 9th edition. Varanasi; Chaukhambha Orientalia; 2005, 402p.

31. Sharma RK, Dash B. English translation on Charaka Samhita of Agnivesha, Volume 2, Vimana Sthana; RogabhishagiteeyamVimanam: Chapter 8, Verse 97: Reprint edition.Varanasi; Chowkhambha Sanskrit Series; 2014, 263-64p.

32. Acharya YT. Sushruta Samhita with Nibandhasangraha commentary of Sri Dalhanacharya. Reprint edition. Varanasi; Chaukambha Sanskrit Samsthan; 2010, 361p.

33. Paradakara HSS. Ashtanga Hrudaya with Sarvangasundara commentary of Arunadutta and Ayurveda Rasayana commentary of Hemadri. 9 edition. Varanasi; Chaukhambha Orientalia; 2005, 403p.

34. Sharma RK, Dash B. English translation on Charaka Samhita of Agnivesha, Volume 2, Vimana Sthana; Rogabhishagjiteeyam Vimanam: Chapter 8, Verse 96: Reprint edition.Varanasi; Chowkhambha Sanskrit Series; 2014, 263p.

35. Acharya YT. Sushruta Samhita with Nibandhasangraha commentary of Sri Dalhanacharya, Reprint edition. Varanasi; Chaukambha Sanskrit Samsthan; 2010, 361p.

36. Paradakara HSS. Ashtanga Hrudaya with Sarvangasundara commentary of Arunadutta and Ayurveda Rasayana commentary of Hemadri. 9th edition. Varanasi; Chaukhambha Orientalia; 2005, $404 p$.

37. Sharma RK, Dash B. English translation on Charaka Samhita of Agnivesha, Volume 2, Shareera Sthana; Katidhapurusheeyam: Chapter 1, Verse 102-109: Reprint edition.Varanasi; Chowkhambha Sanskrit Series; 2014, 337-338p.

38. Sharma RK, Dash B. English translation on CharakaSamhita of Agnivesha, Volume 2, Shareera Sthana; Katithapurusheeyam: Chapter 1, Verse 102: Reprint edition.Varanasi; Chowkhambha Sanskrit Series Publishers; 2014. 337p.

39. ht tps: / / e n.wikipedia.org/wiki/ Inte 11 igence_quotient \# Ge ne environment_interaction dated 18-05-2021 time 13.05 IST

40. ht tp s://e n.wikipedia.org/wiki/ Intelligence_quotie nt \# G e n e environment_interaction dated 18-05-2021 time 13.05 IST

41. https://pubmed.ncbi.nlm.nih.gov/2777491/ dated 15-05-2021 time 14.28 IST.

42. h t t p s:// e n.wikipedia.org / wi ki / Intelligence_quotient\#Social_correlations dated 16-05-2021 time 10.00 IST. 